\title{
Physician Employee Non-Compete AgReEMents on the Examining Table: The NeEd to Better Protect Patients' aNd The Public's InTERests in Indiana
}

\author{
Kevin D. Koons*
}

\section{TABLE OF CONTENTS}

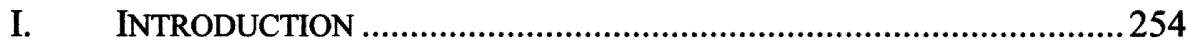

II. BACKGROUND: EMPLOYEE NON-COMPETE AGREEMENTS IN THE

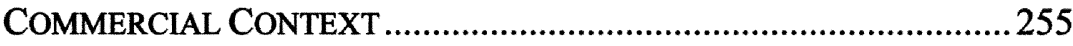

A. Common Law Rule: Covenants Not to Compete Are Per Se

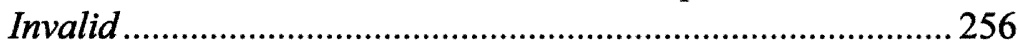

B. Modern "Rule of Reason": Non-Compete Agreements Are

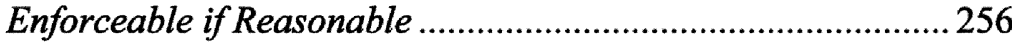

C. Indiana's Approach: The "Rule of Reason"...........................257

III. PHYSICIAN EMPLOYEE NON-COMPETE AGREEMENTS ...................258

A. Approaches to the Problem ........................................................ 258

1. Modern Commercial "Rule of Reason" ...............................258

2. Rule of Per Se Invalidity ......................................................259

3. Intermediate Approach: A Stricter Application of the "Rule of Reason".

B. Development of the Standards for Reviewing Physician NonCompete Agreements in Indiana

IV. ANALYSIS: PROPOSAL FOR A MORE DEMANDING REVIEW OF PHYSICIAN RESTRICTIVE COVENANTS .

A. Determine the Genuinely Legitimate, Protectable Interests of Medical Practice Groups.

B. Full Consideration of Public Interests Affected by Physician

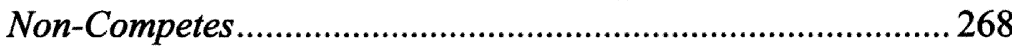

1. Public Interests Favoring Enforcement ..............................2269

2. Public Interests Disfavoring Enforcement ...........................271

C. The Circumstances Surrounding the Physician's Departure... 281

1. Voluntary Resignation or Termination for Cause ..............282

2. Bad Faith Termination ....................................................... 283

3. Good Faith Termination Without Cause .............................. 284

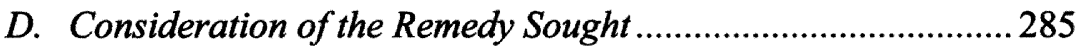

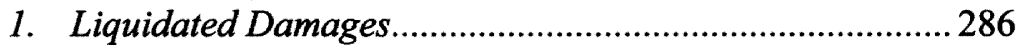

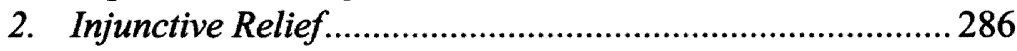

* J.D. Candidate, 2008, Indiana University School of Law - Indianapolis; J.D., 2003, Oak Brook College of Law and Government Policy. 


\section{E. Heightened Burden of Proof for Enforcement: Clear and} Convincing Evidence.

V. CONCLUSION

\section{INTRODUCTION}

The issues surrounding physician non-compete agreements ${ }^{1}$ highlight a clash of competing interests, rights, and individual freedoms. On one hand, enforcing physician covenants not to compete, there are the legitimate business interests of employers and physician practice groups to consider, as well as the freedom and sanctity of contract. On the other hand, society has an interest in promoting a free marketplace, in preventing monopolies, and in ensuring the fullest availability of professional medical assistance. Additional considerations favoring unenforceability are a physician's right to work and the interests of patients in choosing their own doctors, including the ability to follow their doctor to a different practice group.

Physician restrictive covenants appear in various types of agreements, including employment agreements, ${ }^{2}$ partnership agreements, ${ }^{3}$ and agreements for the sale of a medical practice. ${ }^{4}$ While restrictive covenants in these differing contexts raise discrete issues, ${ }^{5}$ this Note is limited to covenants not to compete that are incidental to physician employment agreements. In addition to a noncompete clause, these employment agreements may also include a nonsolicitation of patients provision and a liquidated damages clause- or some combination of the three. ${ }^{6}$ This Note focuses primarily on the non-compete clause, although the other two elements are incidentally considered. With respect to enforcement, employers will seek either injunctive relief to enjoin the

1. This Note uses the terms "non-compete agreement," "covenant not to compete," and "restrictive covenant" interchangeably.

2. Ferdinand S. Tinio, Annotation, Validity and Construction of Contractual Restrictions on Right of Medical Practitioner to Practice, Incident to Employment Agreement, 62 A.L.R.3d 1014 (1975).

3. See, e.g., Rash v. Toccoa Clinic Med. Ass'n, 320 S.E.2d 170 (Ga. 1984); see also Ferdinand S. Tinio, Annotation, Validity and Construction of Contractual Restrictions on Right of Medical Practitioner to Practice, Incident to Partnership Agreement, 62 A.L.R.3d 970 (1975).

4. Ferdinand S. Tinio, Annotation, Validity and Construction of Contractual Restrictions on Right of Medical Practitioner to Practice, Incident to Sale of Practice, 62 A.L.R.3d 918 (1975).

5. See, e.g., Reed, Roberts Ass'n, Inc. v. Strauman, 353 N.E.2d 590 (N.Y. 1976) (covenant not to compete ancillary to sale of business). Restrictive covenants that are ancillary to the sale of a business have different objectives than covenants ancillary to employment agreements. For a discussion of the difference between the objectives of an employee non-compete agreement and that of the seller of a business, see Harlan M. Blake, Employee Agreements Not to Compete, 73 HARV. L. REV. 625, 646-47 (1960).

6. For an example of a physician restrictive covenant that included all three elements, see Sharvelle v. Magnante, 836 N.E.2d 432, 434-35 (Ind. Ct. App. 2005). 
activities prohibited by the restrictive covenant or, if the contract includes them, liquidated damages.

Until recently, the Indiana Supreme Court had confronted physician noncompete agreements only once in its 1983 decision of Raymundo v. Hammond Clinic Association. ${ }^{7}$ The Raymundo court upheld the physician non-compete agreement without much thought to the public interests implicated by such agreements. ${ }^{8}$ In 2008, Central Indiana Podiatry, P.C. v. Krueger ${ }^{9}$ presented an opportunity for the Indiana Supreme Court to revisit the issue. In the intervening twenty-five years between Raymundo and Krueger, other jurisdictions began to scrutinize physician non-competes more closely than non-compete agreements in other contexts. For example, in 2005, the Tennessee Supreme Court forged a new path by declaring that physician non-compete agreements are per se invalid in violation of public policy. ${ }^{10}$ Other states adopted statutes prohibiting or severely limiting physician non-compete agreements. ${ }^{11}$ In Krueger, however, the Indiana Supreme Court declined to join those jurisdictions that hold physician non-compete agreements to a higher standard of review.

The purpose of this Note is to explore and evaluate possible standards for reviewing physician restrictive covenants and to suggest an analytical framework for this issue. Part II of this Note gives a brief overview of the standards that courts have traditionally applied to non-compete agreements in ordinary commercial contexts. Part III discusses and evaluates the three primary approaches - including Indiana's approach - that courts use to analyze physician restrictive covenants. Part IV proposes an analytical framework and various factors for subjecting restrictive covenants to more rigorous scrutiny in light of the important public interests at stake.

\section{BACKGROUND: EMPLOYEE NON-COMPETE AGREEMENTS IN THE COMMERCIAL CONTEXT}

It is difficult to appreciate the problem of non-compete agreements in the specific context of physician employees without first considering how courts evaluate the validity of employee non-compete agreements in general commercial contexts. Briefly reviewing the development of the law of noncompete agreements in the commercial setting will give an appropriate context for examining noncompete agreements as applied to physician-employees. An over-

7. 449 N.E.2d 276 (Ind. 1983).

8. Id. at 280 .

9. 882 N.E.2d 723 (Ind. 2008).

10. Murfreesboro Med. Clinic, P.A. v. Udom, 166 S.W.3d 674, 683 (Tenn. 2005). The Tennessee General Assembly, however, responded in 2007 by enacting legislation to permit physician non-compete agreements with certain specified limitations. TENN. CODE ANN. § 63-1148 (2007).

11. See, e.g., Del. Code ANN. tit. 6, § 2707 (enacted in 1993); Colo. Rev. Stat. ANN. § 8-2-113(3) (enacted in 2003); MASs. GEN. LAWS ANN. ch. 112, § $12 \mathrm{X}$ (enacted in 1991). 
view of this development follows. ${ }^{12}$

\section{A. Common Law Rule: Covenants Not to Compete Are Per Se Invalid Restraints on Trade}

The use of covenants not to compete is not a new phenomenon. Some of the earliest cases at English common law date back to 1414, holding that an employee's covenant not to compete was per se void, as were all restraints on trade. ${ }^{13}$ This early line of cases involved apprentices or journeymen who faced "'unethical' masters attempting to prolong the traditional period of [training]." I4 In contexts other than employment, common law courts began to uphold "partial" restraints on trade, namely, restrictions that had a limited scope of prohibited activities or geographic restriction. ${ }^{15}$ These cases, however, involved covenants not to compete that were incidental to the sale or transfer of a business. $^{16}$

\section{B. Modern "Rule of Reason": Non-Compete Agreements Are Enforceable if Reasonable}

Covenants in restraint of trade are still disfavored today, yet courts are willing to enforce them if they are reasonable. ${ }^{17}$ To qualify as "reasonable," the covenant must (1) be no greater than necessary to protect the employer's interests, (2) not impose an undue hardship on the employee, and (3) not harm the public. $^{18}$

Commonly recognized protectable interests include the goodwill that the employer has built among its customers as well as any confidential information that the employer imparted to the employee during his employment. ${ }^{19}$ If the employer can identify a legitimate interest worthy of protection, courts next consider whether the covenant is no broader than necessary to protect that interest, considering any (1) time limitations, (2) limitations on the scope of prohibited activities, and (3) geographic limitations on the covenant's reach. ${ }^{20}$

12. The full history and development of the law concerning general employee noncompete agreements is beyond the scope of this Note. For a thorough discussion of the law's development, see Blake, supra note 5. For a similar discussion specific to Indiana law, see John W. Bowers, Stacey L. Katz \& Charles W. Back, Covenants Not to Compete: Their Use and Enforcement in Indiana, 31 VAL. U. L. REV. 65 (1996).

13. Blake, supra note 5, at 631-37.

14. Id. at 632 .

15. Id. at 632,635 .

16. Id.

17. Licocci v. Cardinal Assocs., Inc., 445 N.E.2d 556, 561 (Ind. 1983).

18. Blake, supra note 5, at 648-49 (citing RESTATEMENT (FIRST) OF CONTRACTS $§ \S 513-$ 15 (1932).

19. See generally id. at 651-74 (discussing commonly recognized protectable business interests).

20. E.g., Dicen v. New Sesco, Inc., 839 N.E.2d 684, 688 (Ind. 2005). 
Although the traditional formulation of the rule requires courts to consider all three factors (i.e., employer's interests, hardship on the employee, and injury to the public), most courts consider only whether the covenant seeks to protect some legitimate business interest, almost to the exclusion of the other two factors. ${ }^{21}$ Considerations of hardship on the employee or of injury to the public are often subsumed in the courts' evaluation of the first factor. ${ }^{22}$ As one scholar has noted, this almost exclusive focus on an employer's protectable interest "does not mean that the interests of the employee and the public are necessarily slighted, but only that 'undue hardship' to the employee and 'injury' to the public are measured against the urgency of the employer's claim to protection, rather than against some extrinsic standard."23 This approach may suffice where the public interests at stake are limited either to economic interests (such as the need for efficient business operation and the large-scale economic costs of limiting an employee's right to work) or to social concerns that relate to economic interests (such as the sanctity of contract and an employee's right to work). ${ }^{24}$ After all, the employer's protectable interests generally relate to its own economic concerns. But where the public has an interest in other, non-economic concerns, such as public health, welfare, or safety, these interests should not be collapsed into the "legitimate employer interest" factor. Rather, decisional transparency, analytical clarity, and public confidence in the judiciary require courts to engage in a separate and deliberate evaluation of the covenant's effect on the public's non-economic interests.

\section{Indiana's Approach: The "Rule of Reason"}

Like other jurisdictions adopting the modern rule, the touchstone of Indiana's inquiry into the validity of a covenant restraining trade is the covenant's reasonableness. $^{25}$ In considering what is reasonable, Indiana courts likewise consider the three factors of (1) whether the covenant's scope is broader than necessary to protect the employer's legitimate interests, (2) the hardship upon the employee, and (3) the effect upon the public's interest. ${ }^{26}$ Physician Employee Non-Compete Agreements

21. Blake, supra note 5, at 649-50.

22. Id. at 684-87.

23. Id. at 650 .

24. Id. at $650-51$.

25. See Donahue v. Permacel Tape Corp., 127 N.E.2d 235, 239 (Ind. 1955) (quoting WILLISTON ON CONTRACTS, $\S 1636$, at 4580-81).

26. Id. 


\section{PHYSICIAN EMPLOYEE NON-COMPETE AGREEMENTS}

\section{A. Approaches to the Problem}

In the context of physician employee covenants not to compete, courts will at least recite the traditional formulation of the rule. The cases, however, often diverge on how or whether to apply the third factor, which involves the covenant's effect on the public's interest. At one end of the spectrum, some courts continue to gloss over the traditional "public interest" factor when analyzing physician non-compete agreements. They focus instead on whether the scope of the covenant is broader than necessary to serve the employer's protectable interests. ${ }^{27}$ At the other end of the spectrum, at least one court has held that an employer's protectable interests can never outweigh the public's interest in the free availability of a physician's services. ${ }^{28}$

Within this spectrum, the approaches to physician non-compete agreements can be generalized into the following categories: (1) the modern "rule of reason" as applied in general commercial contexts, where the "public interest" factor is essentially subsumed in the analysis of the covenant's relationship to the employer's protectable interest, (2) a rule of per se invalidity based on a policy judgment that any restrictions on the right to practice medicine are inimical to the public interest, and (3) an intermediate approach that more strictly applies the "rule of reason" by separately and deliberately analyzing and weighing the covenant's effect on the public interest. Each of these approaches is briefly discussed below.

\section{Modern Commercial "Rule of Reason"}

Although courts frequently recite all three factors that comprise the traditional formulation of the test for the enforceability of non-compete agreements, in practice they analyze only the first factor and gloss over, if not altogether ignore, the public interest factor when evaluating physician non-compete agreements. ${ }^{29}$ Some courts follow this approach even in the context of physician non-compete agreements without stopping to consider the breadth of interests that such agreements implicate. ${ }^{30}$ As noted above, if the public's interests are limited to economic concerns, the public interest may be adequately represented in the "legitimate employer interest" factor of the test." ${ }^{31}$ But physi-

27. See, e.g., Raymundo v. Hammond Clinic Ass'n, 449 N.E.2d 276, 281 (Ind. 1983) (summarily dismissing as "self-serving" physician employee's argument that the public need for medical services is great).

28. Murfreesboro Med. Clinic, P.A. v. Udom, 166 S.W.3d 674, 683 (Tenn. 2005).

29. See, e.g., Raymundo, 449 N.E.2d at 281 (summarily dismissing as "self-serving" physician employee's argument that covenant should not be enforced due to the public interest in the availability of medical services).

30. Id.

31. See supra notes $21-24$ and accompanying text. 
cian non-compete agreements affect a much broader range of interests than economic concerns alone. The potential public effects of such agreements include reducing the availability of medical services in the restricted geographic area and impeding a patient's ability to seek continued care from a treating physician. That is not to say, however, that economic concerns are absent in physician restrictive covenants. Rather, the public health and welfare concerns are in addition to the same social and economic effects that are found in all commercial employee non-compete agreements. Because the public effects of physician non-compete agreements are broader than the public effects of general commercial non-compete agreements, courts should not merely subsume the "public injury" inquiry in its evaluation of the employer's legitimate protectable interest when analyzing the reasonableness of a physician restrictive covenant. Instead, the covenant's effect on the public health and welfare should be given its own due consideration.

\section{Rule of Per Se Invalidity}

While some courts apply the "rule of reason" without adequately considering the covenant's effect on the public good, others have advocated an approach at the opposite extreme. These courts at the opposite extreme hold that all physician restrictive covenants are per se unenforceable as being against the public interest. $^{32}$ This approach has the advantages of recognizing the covenant's adverse effects on the public interest and maintaining the certainty that accompanies bright line rules. This certainty allows both physician practice groups and the doctors they employ are able to arrange their respective business relationships without speculating whether a restrictive covenant will be enforced.

As with many bright line rules, the problem with this approach is that its one-size-fits-all solution may not always be appropriate. Not all physician noncompete agreements pose the same threat to the public good. In fact, some physician non-compete agreements may arguably further the public's interest in making medical services as widely available as possible. For example, some geographic areas are medically underserved while others have an adequate supply of physicians, if not a surplus. ${ }^{33}$ If a physician is already located in an

32. See, e.g., Murfreesboro, 166 S.W.3d at 684, superseded by statute, Act of June 21, 2007, ch. 487, §1, 2007 Tenn. Pub. Acts, ch. 487, §1 (codified at TeNN. CoDE ANN. § 63-1-148 (2007)); Gomez v. Chua Med. Corp., 510 N.E.2d 191, 197-98 (Ind. Ct. App. 1987) (Sullivan, J., concurring); S. File 210, 74th Gen. Assem. (Iowa 1991), available at $\mathrm{http}: / /$ contentdm.legis. state.ia.us/cdm4/document.php?CISOROOT $=/ 74$ bills $\&$ CISOPTR $=14440 \& R E C=1$ (vetoed by the Governor on June 5, 1991); Paula Berg, Judicial Enforcement of Covenants Not to Compete Between Physicians: Protecting Doctors' Interests at Patients' Expense, 45 RUTGERS L. REV. 1, 48 (1992).

33. At the writing of this Note, only twenty-five of Indiana's ninety-two counties do not contain a "Medically Underserved" or "Health Professional Shortage" area, as determined by the U.S. Department of Health and Human Services. U.S. DEP'T OF HEALTH AND HUMAN SERV., 
adequately served area, enforcing his non-compete agreement could force him to move into a medically underserved area. ${ }^{34}$ Thus, enforcing the restrictive covenant in such cases would actually better serve the public's interest in making the physician's services more widely available to areas that have greater need of them. This view, however, is tempered by (1) the reality that these circumstances probably arise rather infrequently ${ }^{35}$ and (2) the highly speculative nature, even in a concrete case, of determining whether the physician employee would actually move to a medically underserved area as opposed to moving to another adequately served area. ${ }^{36}$ Thus, these observations suggest that a per se rule of invalidity is not the preferable approach.

A health care employer's reliable access to the restrictive covenant device arguably increases the availability of medical services in another way. If restrictive covenants are off limits to health care employers, they may be less willing to employ additional physicians, particularly younger physicians who need to develop a practice but may not be in the position, financial or otherwise, to enter a particular medical market. ${ }^{37}$ Therefore, preventing health care employers from using restrictive covenants could actually decrease the availability of medical services. But if they can protect their investment in additional employees through the use of restrictive covenants, the public's access to medical services would be increased. The question in any given case would be: To what extent will the unavailability of the restrictive covenant actually discourage employers from hiring additional physicians? And, assuming such effects could be measured, how do they compare with any current physician shortages (or surpluses) in the subject geographic area? As these issues demonstrate, the one-size-fitsall approach of both the modern commercial "rule of reason" and the "rule of

Health Res. and Serv. Admin., Health Professional Shortage areas, http://hpsafind.hrsa.gov/HPSASearch.aspx (search "Indiana," "All Counties," and "Primary Medical Care") (last visited Nov. 10, 2007) [hereinafter HEALTH ProfESSIONAL SHORTAGE AREAS]; U.S. DEP'T OF HEALTH AND Human SERV., HEALTH RES. AND SERV. ADMIN., MEDICALly UNDERSERVED AREAS, http://muafind.hrsa.gov/index.aspx (search "Indiana" and "All Counties") (last visited Nov. 10, 2007) [hereinafter MEDICALLY UNDERSERVED AREAS].

34. Rash v. Toccoa Clinic Med. Ass., 320 S.E.2d 170, 173-74 (Ga. 1984) (recognizing that enforcing a physician restrictive covenant would equally afford people in other areas the opportunity to have the services of another physician available in their locale).

35. At the writing of this Note, more than two-thirds of Indiana's counties are classified by the U.S. Department of Health and Human Services as either a "Medically Underserved Area" or a "Health Professional Shortage Area" for the discipline of "Primary Medical Care." HEALTH Professional ShORTAGe AREAS, supra note 33; MEDICALly UNDERSERVED AREAS, supra note 33.

36. While a court could restrain the physician-employee from practicing within the geographic area that is subject to the restrictive covenant, it is unlikely that a court would have the authority to coerce the physician to practice in a medically underserved area against his or her will.

37. For example, physicians who are just starting their careers most likely do not have the patient base or financial resources to open their own practice. These younger physicians may need to join an existing practice in order to develop the financial resources and patient base needed to open a practice. An existing practice group, however, may not be willing to hire a young physician without some assurance that the physician-employee will not leave the practice until the physician-employee has generated enough revenue to cover the practice group's expenses and produce a profit. 
per se invalidity" oversimplifies the solution to an exceedingly complex and sensitive problem.

\section{Intermediate Approach: A Stricter Application of the "Rule of Reason"}

Several state courts have attempted to develop an intermediate approach in an apparent response to the problems inherent in the two previous approaches. These courts give greater attention to the public policy concerns-other than economic interests - that physician restrictive covenants implicate. In Valley Medical Specialists v. Farber, ${ }^{38}$ the Arizona Supreme Court expressly declined to consider a rule of per se invalidity for physician restrictive covenants ${ }^{39}$ and held that physician restrictive covenants must be "strictly construed for reasonableness." In strictly scrutinizing the restrictive covenant, the court separately and fully considered the public interests surrounding the highly sensitive and personal relationship between patients and physicians, ${ }^{41}$ noting that physician restrictive covenants could not be compared to similar commercial covenants. ${ }^{42}$

In Iredell Digestive Disease Clinic, P.A. v. Petrozza, ${ }^{43}$ the North Carolina Court of Appeals also rejected a per se rule of invalidity, instead holding that the restrictive covenant is unenforceable if it creates a "substantial question of potential harm to the public health...."44 The court stated that due to the highly personal relationship between physician and patient, it was "extremely hesitant" to deny the patient-consumer a choice of physicians. ${ }^{45}$ This "extreme hesitance" manifests the court's view that physician restrictive covenants must be subjected to stricter scrutiny under the traditional formulation of the rule than general commercial restrictive covenants.

Similarly, in Ohio Urology, Inc. v. Poll, ${ }^{46}$ the Ohio Court of Appeals expressly rejected the trial court's ruling that all physician noncompetition covenants are per se unenforceable. ${ }^{47}$ The court recognized, however, that while all anti-competitive agreements are disfavored, physician non-compete agreements affect the public interest more significantly than general commercial noncompete agreements.: "[The] measure of disfavor is especially acute concerning restrictive covenants among physicians, which affect the public interest to a much greater degree." ${ }^{, 48}$ The Ohio Urology court acknowledged a variety of

38. 982 P.2d 1277 (Ariz. 1999).

39. Id. at 1283 n.1.

40. Id. at 1283 .

41. Id. at 1285 .

42. Id. at 1283 .

43. 373 S.E.2d 449 (N.C. Ct. App. 1988).

44. Id. at 453 (emphasis added).

45. Id. at 455 .

46. 594 N.E.2d 1027 (Ohio Ct. App. 1991).

47. Id. at 1033 .

48. Id. at 1031 . 
public interest concerns, including (1) the American Medical Association's ("AMA") express ethical opinion discouraging the use of restrictive covenants, (2) the importance of competition in physician services in times of skyrocketing health care costs, and (3) the expectations of patients, who would have no reason to know the specifics of a doctor's private employment agreements. ${ }^{49}$

The approach reflected in these cases involves a more exacting review of physician restrictive covenants to ensure that (1) the employer is truly seeking to protect only legitimate business interests, ${ }^{50}(2)$ the restrictive covenant is narrowly tailored to achieve those interests, ${ }^{51}$ and (3) the public interests, especially noneconomic concerns, are thoroughly vetted and balanced. ${ }^{52}$ This stricter review gives the proper attention to important noneconomic public concern that the modern general commercial approach neglects. Moreover, unlike the per se invalidity approach, it gives employers the chance to show (albeit under a heavier burden than in the general commercial context) that the restrictive covenant is necessary to protect their legitimate business interests.

Admittedly, this intermediate approach lacks the certainty that the "per se invalid" rule provides. This shortcoming, however, should not be fatal for several reasons. First, many factor tests exist in employment law, and litigants in this area should be somewhat conditioned to their use. ${ }^{53}$ Second, any uncertainty inherent in the law might induce parties to resolve their disputes out of court rather than resort to expensive (and uncertain) litigation. Third, physician practice groups may be less likely to use restrictive covenants-or perhaps even be less likely to enforce existing restrictive covenants-if they face an uphill battle to prove the reasonableness of their agreements coupled with the uncertainty of litigation. Given the "acutely disfavored" status of physician restrictive covenants, ${ }^{54}$ this is not a bad result. While a more exacting review of restrictive covenants will eliminate a larger number of "acutely disfavored" agreements, it nonetheless allows employers to use such covenants where necessary and encourages them to draft their covenants more narrowly.

49. Id. at $1031-32$.

50. See infra Part IV.A.

51. See infra Parts IV.A, C and D.

52. See infra Part IV.B.

53. See, e.g., Harris v. Forklift Sys., Inc., 510 U.S. 17, 24-25 (1993) (Scalia, J., concurring) (noting the lack of clarity in the majority's factorial test to determine the existence of a hostile work environment but concurring nonetheless because no better alternative test exists); Moberly v. Day, 757 N.E.2d 1007, 1009-10 (Ind. 2001) (applying a ten-factor test for distinguishing employees from independent contractors); GKN Co. v. Magness, 744 N.E.2d 397, 402 (Ind. 2001) (establishing a seven-factor test for determining whether a person is an employee of two different employers).

54. See, e.g., Ohio Urology, 594 N.E.2d at 1031. 


\section{B. Development of the Standards for Reviewing Physician Non-Compete Agreements in Indiana}

A proper appreciation for the treatment of physician non-compete agreements in Indiana begins, not with jurists, but with Indiana's medical community. Nationally, the medical profession has been debating the ethical propriety of physician restrictive covenants for the last seventy-five years. ${ }^{55}$ Within that debate, Hoosier physicians have advocated the view that any physician restrictive covenant is wholly unethical. In 1971, the Indiana delegation to the AMA House of Delegates "introduced a resolution that unequivocally declared that restrictive covenants were unethical." ${ }^{\text {}}$ The full AMA House of Delegates, however, rejected the Indiana delegation's proposed resolution; instead, it formally adopted an ambivalent "discouragement" of restrictive covenants. ${ }^{57}$

The law in Indiana, however, has not coincided with the opinions of its medical ethicists. When the Indiana Supreme Court first tackled the issue in Raymundo v. Hammond Clinic Association in $1983,{ }^{58}$ the court failed to consider the position of the Indiana medical community. In Raymundo, Dr. Raymundo joined a fifty-physician clinic as part of its four-year partnership track. ${ }^{59}$ The clinic's agreement with Dr. Raymundo provided that he would be subject to a two-year restrictive covenant should he leave the clinic before he became a full partner. ${ }^{60}$ The agreement further provided that if Dr. Raymundo violated the restrictive covenant, the clinic would be entitled to liquidated damages of $\$ 25,000$ if the violation occurred during the first year of the two-year period and $\$ 15,000$ if the violation occurred during the second year. ${ }^{61}$ Two years after joining the clinic, Dr. Raymundo withdrew and started an independent practice in the restricted area. ${ }^{62}$

Upon Dr. Raymundo's violation of the restrictive covenant, the clinic sued both to enjoin Dr. Raymundo from violating his non-compete agreement and to recover liquidated damages. ${ }^{63}$ By the time the case reached the Indiana Supreme Court, the two-year contractual ban on competitive activities had already expired. ${ }^{64}$ Because the two-year restrictive period had expired, the Raymundo court held that the injunction issue was moot. ${ }^{65}$ Thus, Raymundo

55. Berg, supra note 32 , at 6-7.

56. Id. at 7 .

57. Id.

58. 449 N.E.2d 276, 281 (Ind. 1983) ("It appears that the enforceability of noncompetition covenants has not been previously decided in this state, with respect to physicians.")

59. Id. at 278

60. Id.

61. Id.

62. Id.

63. Id. at $278-79$.

64. Id.

65. Id. (" $[\mathrm{W}]$ e are here concerned only with the [claim] seeking damages, [the claim seeking injunctive relief] having become moot with the passage of time, during the pendency of the 
expressly presented only the enforceability of the restrictive covenant's liquidated damages provision rather than the clinic's right to enjoin Dr. Raymundo's practice of medicine. ${ }^{66}$

The Raymundo decision is fraught with decisional opacity. The court applied the modern test that courts apply generally to commercial restrictive covenants but failed to thoroughly discuss the public policy interests at stake. ${ }^{67}$ Rather, it characterized Dr. Raymundo's public policy argument as an egotistical "suggest[ion] that ... he is, somehow entitled to special treatment, because he is a physician and there is great need for his services." ${ }^{" 68}$ The court then summarily dismissed this argument merely as a "self-serving" position. ${ }^{69}$ Finally, the court concluded that physician covenants not to compete "have been upheld generally in other jurisdictions" but provided no authority to support this statement. ${ }^{70}$

Although the restrictive covenant at issue in Raymundo was incident to a partnership agreement, rather than an employment agreement, ${ }^{71}$ subsequent Indiana decisions have applied Raymundo's standards to employment agreements as well. ${ }^{72}$ Despite the lower courts' faithful application of Raymundo to physician restrictive covenants, many decisions have invalidated such covenants on the facts before them. ${ }^{73}$

Four years after Raymundo, the Indiana Court of Appeals, in Gomez v. Chua Medical Corp., recognized Raymundo's apparent shortcomings and urged the Indiana Supreme Court to reexamine and overturn Raymundo: " $[\mathrm{I}] \mathrm{t}$ is not inappropriate, I think, to hope for our Supreme Court to conduct a reexamination of its earlier-stated view [in Raymundo] that the freedom of contract must remain inviolate even if the public policy is disserved." ${ }^{74}$ Not willing to drop the matter, the Indiana Court of Appeals again expressed disagreement with

action in the trial court....").

66. Id.

67. Id. at 280 .

68. Id. at 281 .

69. Id.

70. Id.

71. Id. at 276.

72. See, e.g., Sharvelle v. Magnante, 836 N.E.2d 432 (Ind. Ct. App. 2005); Duneland Emergency Physician's Med. Group v. Brunk, 723 N.E.2d 963 (Ind. Ct. App. 2000); Norlund v. Faust, 675 N.E.2d 1142 (Ind. Ct. App. 1997); Gomez v. Chua Med. Corp., 510 N.E.2d 191 (Ind. Ct. App. 1987).

73. See Sharvelle, 836 N.E.2d at 437-39 (declining to enforce a covenant prohibiting the practice of "health care of every nature and kind" where the physician-employee was hired only to perform ophthalmological services); Duneland, 723 N.E.2d 963 (holding the covenant unenforceable because the clinic suffered no injury other than the typical expenses incurred when a departing employee must be replaced); Norlund, 675 N.E.2d at 1155 (refusing to enforce the portion of the covenant restraining the practice of optometry as long as the physician-employee did not contact optometrists on the referral list for which the physician-employee was specifically hired to develop); Fumo v. Med. Group of Michigan City, Inc., 590 N.E.2d 1103, 1108 (Ind. Ct. App. 1992) (dissolving a preliminary injunction because the trial court's findings failed to address the injunction's effects on the public).

74. Gomez v. Chua Med. Corp., 510 N.E.2d 191, 197-198 (Ind. Ct. App. 1987) (Sullivan, J., concurring, in which Garrard, J., as a second member of the three-judge panel, also joined). 
Raymundo in its 1997 decision in Norlund v. Faust. ${ }^{75}$

In Norlund, an ophthalmologist hired an optometrist to develop a list of referring optometrists. ${ }^{76}$ Their employment agreement specifically required the employee-optometrist to educate other optometrists about the employer's ophthalmological services. ${ }^{77}$ The agreement contained a restrictive covenant that not only prohibited the employee-optometrist from post-employment contact with any person on the developed referral list, but also prohibited the employeeoptometrist from practicing optometry with any ophthalmologist in the listed counties. $^{78}$

The Indiana Court of Appeals viewed Raymundo as holding "that the public's general interest in medical services is subservient to the public interest in the freedom of individuals to contract."79 Constrained by Raymundo, the Norlund court reluctantly held that the non-compete agreement restricting the practice of medicine was not void as a matter of law. ${ }^{80}$ The court determined, however, that the portion of the covenant restraining Dr. Norlund from "performing any services as a[]...medical optometrist" was nonetheless void. ${ }^{81}$ It held that while the employer had an interest in protecting its goodwill, the restriction on the practice of medicine served no purpose other than to "prevent [Dr.] Norlund from practicing his livelihood." ${ }^{, 2}$ The court noted, however, that its disagreement with Raymundo was easier to overcome here because Dr. Norlund was prohibited only from contacting referring optometrists and acting as a salesman-not from providing optometry services. ${ }^{83}$

Most recently, the Indiana Supreme Court considered a physician noncompete agreement in Central Indiana Podiatry, P.C. v. Krueger. ${ }^{84}$ In Krueg$e r$, the employee-physician was subject to a two-year restrictive covenant that included fourteen enumerated counties, plus any county in which the employer maintained an office, and any contiguous counties. ${ }^{85}$ Unlike previous cases in which the employee voluntarily resigned, ${ }^{86}$ the clinic dismissed Dr. Krueger

75. 675 N.E.2d 1142 (Ind. Ct. App. 1997). Two intervening cases of the Indiana Court of Appeals, Fumo v. Med. Group of Michigan City, Inc., 590 N.E.2d 1103 (Ind. Ct. App. 1992) and Med. Specialists, Inc. v. Sleweon, 652 N.E.2d 517 (Ind. Ct. App. 1995), had applied Raymundo's standards, each with opposite results.

76. Norlund, 675 N.E.2d at 1146.

77. Id.

78. Id. at $1146-47$.

79. Id. at 1153 . The majority opinion was authored by Judge Sullivan, who also wrote the concurring opinion in Gomez, urging the Indiana Supreme Court to reexamine its position with respect to the public policy implications of covenants restricting the practice of medicine. While Judge Sullivan's concurring opinion was joined by Judge Garrard in Gomez, Judge Sullivan won over another colleague in that Judge Kirsch also joined his majority opinion in Norlund.

80. Norlund, 675 N.E.2d at 1153-54.

81. Id. at 1159 .

82. Id. at 1155 .

83. Id. at 1154 .

84. Cent. Ind. Podiatry, P.C. v. Krueger, 882 N.E.2d 723 (Ind. 2008).

85. Id. at 726.

86. See, e.g., Raymundo v. Hammond Clinic Ass'n, 449 N.E.2d 276 (Ind. 1983). 
because of multiple incidents of inappropriate conduct with female staff. ${ }^{87}$ Following his termination, Dr. Krueger negotiated employment with one of the clinic's competitors, took the clinic's patient list, and then sent letters to those patients informing them of his change in employment. ${ }^{88}$

The clinic sued for a preliminary injunction to enjoin Dr. Krueger's activities, but the trial court denied it, finding that enforcement would disserve the public interest. $^{89}$ On appeal, the Indiana Court of Appeals reversed, applying the traditional test as required by Raymundo. ${ }^{90}$ Rather than evaluating the covenant's impact on the public interest, the court of appeals simply recited Raymundo's statement that "the public interest in the freedom of individuals to contract" is "paramount."

The Indiana Supreme Court, however, affirmed in part the trial court's denial of the injunction, finding that the restrictive covenant was unenforceable, except in a limited geographic area. ${ }^{92}$ Unlike Raymundo, which summarily dismissed the physician's public policy arguments as "self-serving," Krueger court admirably included a more thorough discussion of the public policy effects of physician non-compete agreements. ${ }^{94}$ While it explicitly rejected a per se rule of invalidity, ${ }^{95}$ the standard it applied is not entirely clear. On the one hand, the court indicated that it would continue to apply Raymun$d o$ 's "reasonableness" standard, ${ }^{96}$ which gives no special consideration to physician non-competes. ${ }^{97}$ On the other hand, the Krueger court stated that "[noncompete] agreements by physicians should be given particularly careful scrutiny." 98

The problem with the decision in Raymundo, as well as the decisions that followed in its steps, is the oversimplification of the complex "public interest" question. The public has more at stake than merely an "interest in the freedom of individuals to contract." 99 The Krueger court appears to acknowledge that physician non-compete agreements are deserving of more careful judicial scru-

87. Krueger, 882 N.E.2d at 726; see also Cent. Ind. Podiatry, P.C. v. Krueger, 859 N.E. 2d 686, 689 (Ind. Ct. App. 2007), vacated, 882 N.E.2d 723 (Ind. 2008).

88. Krueger, 882 N.E.2d at 726.

89. Id.; Krueger, 859 N.E.2d 686, 691.

90. Krueger, 859 N.E.2d 686, 692-696.

91. Id. at 696 .

92. Krueger, 882 N.E.2d at 734.

93. Raymundo v. Hammond Clinic Ass'n, 449 N.E.2d 276, 281 (Ind. 1983).

94. Krueger, 882 N.E.2d at 727-28.

95. Id. at 728 .

96. Id. The Krueger court noted that "Raymundo has been on the books for over twenty years" and indicated agreement with the Supreme Court of Illinois in Mohanty v. St. John Heart Clinic, S.C., 866 N.E.2d 85 (Ill. 2006), which held that it would not "deviat[e] from [Illinois'] longstanding practice of finding reasonable restrictive covenants in medical employment contracts enforceable...." Id. (quoting Mohanty v. St. John Heart Clinic, S.C., 866 N.E.2d 85, 95 (IIl. 2006).

97. See supra text accompanying notes 58-70.

98. Krueger, 882 N.E.2d at 729.

99. Raymundo v. Hammond Clinic Ass'n, 449 N.E.2d 276, 280 (Ind. 1983). 
tiny than non-compete agreements in the general commercial context, ${ }^{100}$ but failed to clarify the applicable standard for a heightened scrutiny. The next Part proposes a framework for a more demanding review of physician restrictive covenants that will give greater weight to the public's interests and yet take into account the employer's interests in realizing a return on its investment in its employees.

\section{ANALYSIS: PROPOSAL FOR A MORE DEMANDING REVIEW OF PHYSICIAN RESTRICTIVE COVENANTS}

Because physician restrictive covenants implicate broader public interests than do general commercial restrictive covenants, such covenants should be reviewed under a more demanding level of scrutiny. The question remains, however, what factors - other than economic concerns - should Indiana law take into consideration in determining the reasonableness of the physician restrictive covenant? This Part examines several avenues that could be taken, at various steps in the traditional analysis, to achieve a more demanding review of physician non-compete agreements.

\section{A. Determine the Genuinely Legitimate, Protectable Interests of Medical Practice Groups}

Some courts have been fairly generous to physician-employers by broadly construing the scope of the employer's legitimate protectable interests. For example, in Medical Specialists, Inc. v. Sleweon, the Indiana Court of Appeals held that the continued success of the employer's practice was a legitimate protectable interest: "Clearly, the continued success of the practice, which is dependent upon patient referrals, is a legitimate interest worthy of protection."101 It is difficult to imagine any action taken by the employer that would not serve the goal of "continued success of the business."

A more stringent review of physician covenants can be accomplished by narrowing the scope of legitimate protectable interests of physician employers. This narrowing is exemplified by the view that the employer's only legitimate interest is to prevent the employee from unlawfully using some advantage at the employer's expense that is not generally available to the public, i.e., trade secrets. ${ }^{102}$ While some courts have held that an employer's list of patients is a legitimate protectable interest if kept confidential, ${ }^{103}$ other courts have held that

100. Krueger, 882 N.E.2d at 729.

101. Med. Specialists; Inc. v. Sleweon, 652 N.E.2d 517, 523 (Ind. Ct. App. 1995). The Sleweon court relied on the fact that Dr. Sleweon had no ties to Indiana before he was recruited by his employer and thus enriched his patient base at the expense of his employer.

102. Norlund v. Faust, 675 N.E.2d 1142, 1154 (Ind. Ct. App. 1997) (citing Jenkins v. King, 65 N.E.2d 121 (Ind. 1946).

103. Duneland Emergency Physician's Med. Group v. Brunk, 723 N.E.2d 963, 966 (Ind. Ct. App. 2000) (quoting Donahue v. Permacel Tape Corp., 127 N.E.2d 235, 240 (Ind. 1955)). 
customer lists are not a legitimate interest if the information contained in the lists has not been kept confidential and is readily available to the public.$^{104}$

At least one Indiana case applied this prong more firmly. In Duneland Emergency Physician's Medical Group v. Brunk, ${ }^{105}$ although the medical group's physicians provided services to many individual patients, they treated all of those patients at the same hospital under a contract between the hospital and the medical group. Under the contract, the hospital paid the medical group for its services and then billed the patients directly. ${ }^{106}$ Pursuant to this arrangement, the court determined that the individual patients were the hospital's customers - not the medical group's. ${ }^{107}$ Rather, the court found that the medical group's only customer was the hospital itself. ${ }^{108}$ When the medical group's employee left to work for another hospital, the medical group sought to enforce its restrictive covenant. ${ }^{109}$ The court held that because the medical group serviced only one hospital, its customer base was not threatened by the employee's move to another hospital, which serviced entirely different patients. ${ }^{110}$ The court astutely recognized that the medical group could show no harm "other than the typical expenses incurred when a departing employee has to be replaced." 111 Thus, as in Duneland, one way to engage in a more demanding review of physician restrictive covenants is to firmly require the employer to demonstrate a protectable interest. If the employer's only harm is the typical expenses associated with replacing a departing employee, the employer has failed to carry its burden of proving a legitimate protectable interest.

\section{B. Full Consideration of Public Interests Affected by Physician Non-Competes}

Courts should consider public interests other than economic concerns when determining the reasonableness of physician restrictive covenants. While the various public interests are discussed in more detail below, a preliminary observation is in order. Although the employer bears the burden of proving the reasonableness of a restrictive covenant, ${ }^{112}$ under the traditional formulation of the rule, this factor is stated in the negative. Thus, the employer must prove the negative by showing that enforcement of the non-compete provision will not harm the public interest. Because proving the negative is a difficult task, the burden of showing some harm to the public interest, as a practical matter, really

104. Am. Shippers Supply Co. v. Campbell, 456 N.E.2d 1040, 1044 (Ind. Ct. App. 1983).

105. Duneland, 723 N.E.2d at 963.

106. Id. at 966 .

107. Id.

108. Id.

109. Id. at 965 .

110. Id. at $966-67$.

111. Duneland, 723 N.E.2d. at 967.

112. See, e.g., Valley Med. Specialists v. Farber, 982 P.2d 1277, 1286 (Ariz. 1999) (party seeking to enforce the restrictive covenant bears the burden of persuasion). 
falls on the physician employee. Litigants should be aware of this apparent reversal of the burden allocations. ${ }^{113}$ Courts may be limited in their decisionmaking if the physician-employee fails to bring the full scope of the harm done to the public interests to the court's attention.

\section{Public Interests Favoring Enforcement}

While many public policy considerations weigh against enforcement, there are also some public policy implications favoring enforcement. First, some authorities have expressed the view that because medical boards-not courts - are charged with regulating physician conduct, courts should defer to those medical boards. ${ }^{114}$ For example, in Karlin $v$. Weinberg, the court acknowledged that the AMA's current code of ethics, while strongly discouraging non-compete agreements, does not expressly prohibit them outright. ${ }^{115}$ In Indiana, physicians are regulated and disciplined by the Medical Licensing Board of Indiana, ${ }^{116}$ which has promulgated its own standards of practice. ${ }^{117}$ These standards, however, do not prohibit physicians from entering into non-compete agreements. ${ }^{118}$

In most cases, this demonstration of judicial restraint would be laudable. Indeed, the legislative branch - not the judicial branch-is responsible for setting the policy goals of the law. ${ }^{119}$ In the context of non-compete agreements, however, the traditional formulation of the common law rule charges the judiciary with determining whether enforcement of a particular restrictive covenant will harm the public good. ${ }^{120}$ Courts are duty-bound to make this determination, notwithstanding their reluctance to formulate public policy. If the Legislature is concerned about courts usurping its power under the common law rule, it certainly has the power to change the rule or to make its own policy statement. In fact, a number of state legislatures have responded by affirming, modifying, or superseding judicial decisions that weigh the respective interests implicated by physician restrictive covenants. These states include: Colorado, ${ }^{121}$ Delaware, ${ }^{122}$ Massachusetts, ${ }^{123}$ and Tennessee. ${ }^{124}$ Presently, the Indiana General

113. For a discussion of imposing a heightened burden of proof on the employer, see infra Part IV.E. 2005).

114. See, e.g., Intermountain Eye and Laser Ctrs. v. Miller, 127 P.3d 121, 132 (Idaho

115. Karlin v. Weinberg, 390 A.2d 1161, 1168 n.6 (N.J. 1978).

116. IND. CODE § 25-22.5-2-7 (West 2008).

117. See generally 844 IND. ADMIN. CODE 5-2-1 to -22 (2008).

118. Id.

119. See, e.g., Fla. Dept. of Revenue v. Piccadilly Cafeterias, Inc., 128 S.Ct. 2326, 2339

(2008); Kaser v. Barker, 811 N.E.2d 930, 932-33 (Ind. Ct. App. 2004).

120. See supra Part II.B.

121. Colo. Rev. Stat. ANN. § 8-2-113(3) (enacted in 2003).

122. Del. CODE ANN. tit. 6, $\$ 2707$ (enacted in 1993).

123. MASS. GEN. LAWS ANN. ch. $112, \S 12$ X (enacted in 1991).

124. TENN. CODE ANN. $\S 63-1-148$ (enacted in 2007). Iowa also attempted to do so in 
Assembly has not enacted a physician non-compete policy, and Indiana courts should therefore be willing to make those policy judgments without fear of overstepping their bounds. ${ }^{125}$

Second, the public has an important interest in protecting the freedom of contract. $^{126}$ The sanctity of contract should be inviolate where a party freely binds himself to his own detriment. But what if the contract adversely affects important interests of persons who were not party to the contract and were in no position to become a party to the contract? Arguably, the sanctity of contract should be relaxed where the rights of third persons, and particularly the public, are adversely affected. As discussed elsewhere in this Note, ${ }^{127}$ the right of a patient to choose his or her treating physician is adversely affected by physician restrictive covenants. The traditional formulation of the rule already takes into consideration the sanctity of contract by balancing it against other harms to the public interest. ${ }^{128}$ If the freedom of contract always prevails, there is no point in considering any harm to the public's interest. Thus, a rote adherence to the freedom and sanctity of contract is redundant, neglects public interest, and should be avoided.

Third, allowing restrictive covenants may encourage investment in the development of younger physicians. As in many industries, it often takes several years for employers to recoup their initial investment in employee hiring and training. Employers may be reluctant to make the capital investment required to hire and train a young employee, only to have the employee leave and compete against the employer before the employer can even recoup its capital outlay. Arguably, without restrictive covenants to protect against this risk, employers of physicians may be less willing to invest in young physicians, thereby making the services of physicians less available to the public.

Restrictive covenants, however, are not the only means available to protect against this problem. One common feature among physician employment agreements containing restrictive covenants are buyout provisions or liquidated damages clauses that allow the employee to engage in a prohibited activity after termination of employment by paying a predetermined amount to the employ-

1991, but the Governor vetoed the Legislature's efforts, stating that the reasonableness standard applied by Iowa courts adequately balanced the competing interests involved. S. File 210, 74th Gen. Assem. (Iowa 1991); veto letter from the Hon. Terry E. Branstad, Governor of Iowa, to the Hon. Elaine Baxter, Iowa Secretary of State (June 5, 1991), available at http://contentdm.legis.state.ia.us/cdm4/document.php?CISOROOT=/74bills\&CISOPTR=144 40\&REC $=1$.

125. For an example of judicial reluctance to entertain any public policy arguments in this area, see Regional Urology, L.L.C. v. Price, 966 So.2d 1087, 1095 (La. Ct. App. 2007) ("The policy concerns raised by Dr. Price are ... a matter for the legislature to address."). See also Mohanty v. St. John Heart Clinic, S.C., 866 N.E.2d 85, 95 (III. 2006).

126. Robert's Hair Designers, Inc. v. Pearson, 780 N.E.2d 858, 869 (Ind. App. 2002) ("Indiana courts have long recognized and respected the freedom to contract." (quoting Eck \& Assocs., Inc. v. Alusuisse Flexible Packaging, Inc., 700 N.E.2d 1163, 1167 (Ind. Ct. App. 1998)).

127. See discussion of patient rights infra pp. 41-43.

128. See supra Part II.B. 
er. ${ }^{129}$ This mitigating feature not only protects the employer's investment in new employees but also gives the employee the option to compete against the employer for a price. These buyout options can be tailored to the employer's interests by decreasing the buyout amount according to the length of time that the employee stays with the employer, correlating to the employer's anticipated losses should the employee leave before the employer can realize a profit on its investment. For example, a buyout provision might require the employee to pay the employer $\$ 200,000$ if the employee leaves during the first year, $\$ 150,000$ during the second year, $\$ 100,000$ during the third year, and so on. Although a buyout option can also be misused, such as setting the fee exorbitantly high or for an undue length of time, its proper use better balances the public's interest in the availability of medical services because it creates more options. With a buyout provision, the physician-employee has the option to restrict her practice or pay the buyout fee, the purpose of which should be to reimburse the employer its capital investment costs. If patient demand for the departing physician-employee is sufficiently high (indicating a physician shortage under free market economic principles), the departing physician-employee should be able to command a price that justifies paying the buyout fee. By contrast, an injunction provides only one option: restricting the availability of the physician-employee's services, regardless of the public's need for such services. Thus, while there is a public interest in encouraging employers to invest in younger physicians, this goal can be better accomplished if the restrictive covenants are accompanied by a reasonably tailored buyout provision.

Finally, restrictive covenants may help disperse and decentralize physicians by encouraging them to move to rural or medically underserved areas, depending on the facts of the case. Assume, for example, a physician, who lives in a suburban area, works in a metropolitan area under a contract with a restrictive covenant. When the employment relationship terminates, the physician might be more willing to commute to outlying rural communities outside the covenant's geographic scope, rather than move to another major metropoli$\tan$ area. These rural areas often are in need of good doctors. ${ }^{130}$ The problem here is the existence of too many unpredictable variables, such as the geographic scope of the covenant and the physician's post-termination plans, to consistently achieve the goal of dispersing physician services. Courts should nonetheless consider this possibility, if the right facts present themselves.

\section{Public Interests Disfavoring Enforcement}

Until Krueger, Indiana courts, and particularly the Indiana Supreme Court in Raymundo, have overlooked important public interests affected by physician

129. See e.g., Raymundo v. Hammond Clinic Ass'n, 449 N.E.2d 276 (Ind. 1983).

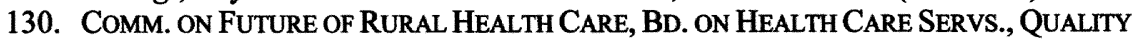
Through Collaboration: The Future of RuRal Health Care 220 (The Nat'l Acads. Press 2005). 
restrictive covenants that should be factored into the traditional test. These various interests are discussed at length below.

a. Medical ethics discourage the use of physician restrictive covenants in all contexts and outright prohibit them in limited contexts

\section{(I) The national position: The American Medical Association}

While not dispositive, one public policy consideration is the position of the AMA. ${ }^{131}$ The current position of the AMA discourages the use of physician restrictive covenants in all contexts. ${ }^{132}$ Moreover, where a restrictive covenant is excessive in scope or duration or "fail[s] to make reasonable accommodation of patients' choice of physician," the AMA's current standards go beyond "discouraging" such covenants and condemn them outright as unethical. ${ }^{133}$

Indeed, a review of the development and evolution of the AMA's position reveals a trend towards stronger ethical prohibitions on restrictive covenants. ${ }^{134}$ Since its founding in 1847, the AMA has written and published its Code of Medical Ethics governing the conduct of physicians. ${ }^{135}$ The 1847 version of the AMA Code of Medical Ethics did not address the ethical propriety of restrictive covenants. ${ }^{136}$ It did, however, contain ethics statements encouraging doctors to view their healing arts as a professional service to the public rather than a business. ${ }^{137}$ Several other provisions recognized the importance of main-

131. The AMA's membership consists of approximately thirty percent (or 300,000) of all U.S. physicians. AM. MED. ASs'N, FREQUENTLY ASKED QUESTIONS IN ETHICS, http://www.amaassn.org/ama/pub/physician-resources/medical-ethics/ama-code-medical-ethics/frequentlyasked-questions.shtml (follow "What can the AMA do about a physician I believe is behaving unethically or unprofessionally?") (last visited Mar. 7, 2009). As a voluntary organization, the AMA does not have power to revoke or suspend physicians' licenses; rather, that function belongs to each state's licensing boards. Id. The AMA's bylaws, however, allow it to take disciplinary action against member physicians with respect to their membership in the organization for unethical conduct. Id.

132. AM. MED. Ass'N, CODE OF MEDICAL ETHICS $\S$ E-9.02 (2009), available at http://www.ama-assn.org/ama1/pub/upload $/ \mathrm{mm} /$ Code_of_Med_Eth/toc.html.

133. Id.

134. The prior AMA position (from 1960 to 1980) was more lenient. It focused on the freedom of contract, allowing for a "reasonable agreement not to practice within a certain area for a certain time, if it is knowingly made and understood." Murfreesboro Med. Clinic, P.A.v. Udom, 166 S.W.3d 674, 679 (Tenn. 2005) (quoting AMA, Principles of Medical Ethics, Opinions, and Reports of the Judicial Council 25 (1960)).

135. AM. MED. Ass'N, ETHICS TIMELINE: 1847-1940, http://www.ama-assn.org/ama/pub/ physician-resources/medical-ethics/ama-code-medical-ethics/about-ama-code-medical-ethics/ history-ama-ethics/ethics-timeline-1847-1940.shtml (last visited Mar. 7, 2009)

136. AM. MED. ASS'N, CODE OF MEDICAL ETHICS (1847), available at http://www.amaassn.org/ama/upload/mm/369/1847code.pdf.

137. See, e.g., id. at ch. II, art. I, $\S 4$ (condemning "secret nostrums" and patents for surgical devices and medicines as being "inconsistent with beneficence and professional liberality") and $i d$. at ch. II, art. I, $\S 3$ (declaring as "derogatory to the dignity of the profession" soliciting individuals with particular diseases via public advertisements and handbills). 
taining an ongoing physician-patient relationship. ${ }^{138}$

The next significant change to the AMA Code of Medical Ethics relating to restrictive covenants occurred in $1922,{ }^{139}$ when the Judicial Council completely prohibited physicians from soliciting patients. ${ }^{140}$ This policy remained in effect until $1980 .^{141}$ Although the AMA Code during this period did not expressly address covenants restricting a physician's right to practice medicine, the direct prohibition on advertising and solicitation of patients would have obviated the need for nonsolicitation provisions that are seen in many of today's physician employment agreements. ${ }^{142}$ Moreover, the other relevant provisions from the 1847 Code of Medical Ethics remained in effect.

In 1957, the AMA restructured its collection of ethics statements and opinions. Until then, the AMA's ethics statements had consisted primarily of its Code of Medical Ethics contained in forty-seven code sections. ${ }^{143}$ In 1957, however, drawing upon the existing Code of Medical Ethics and opinions of the Judicial Council, the AMA distilled the existing code into ten abstract Principles of Medical Ethics. ${ }^{144}$ As a result of this change, the AMA Code of Eth-

138. See, e.g., id. at ch. II, art. V, $\S 6$ (establishing, as a matter of ethics, a preference for a family's regular physician during an emergency) and $i d$. at ch. II, art. V, $\S 7$ (enjoining temporary physicians to relinquish a patient to the care of the patient's regularly treating physician, with the patient's consent, as soon as possible).

139. Although the Code was amended in 1903, only "[m]inor changes were made to the 1847 Code and the title was changed to The Principles of Medical Ethics." AM. MED. Ass'N, TIMELINES OF AMA HISTORY: 1900-1920, http://www.ama-assn.org/ama/pub/about-ama/ourhistory/timelines-ama-history/1900-1920.shtml (last visited Mar. 7, 2009).

140. The AMA established the Judicial Council in 1873 to address ethical and constitutional controversies within the organization. AM. MED. ASs'N, TIMELINES OF AMA HISTORY: 1847-1899, http://www.ama-assn.org/ama/pub/about-ama/our-history/timelines-amahistory/1847-1899.shtml (last visited Mar. 7, 2009). The AMA changed the name of the Judicial Council to the Council on Ethical and Judicial Affairs ("CEJA") in 1985. AM. MED. Ass'N, TIMELINES OF AMA HISTORY: THE 1980s, http://www.ama-assn.org/ama/pub/about-ama/ourhistory/timelines-ama-history/the-1980s.shtml (last visited Mar. 7, 2009). The CEJA continues to serve as the internal body of the AMA that interprets its constitution, bylaws, rules, and ethical principles and that decides individual ethical violations by member physicians. BYLAWS OF THE AM. MED ASs'N $\S 6.52$ (2008), available at http://www.ama-assn.org/ama1/pub/upload $/ \mathrm{mm} / 409 /$ bylaws.pdf.

141. AM. MED. Ass'N, Timelines of AMA History: 1921-1940, http://www.amaassn.org/ama/pub/about-ama/our-history/timelines-ama-history/1921-1940.shtml (last visited Mar. 7, 2009).

142. AM. MED. Ass'N CODE OF MediCAL ETHICs (1847), supra note 136, at ch. II, art. I, § 3 ("It is derogatory to the dignity of the profession, to resort to public advertisements or private cards or handbills....").

143. AM. MEd. Ass'N, PRINCIPles OF MediCAL Ethics (1957), available at http://www.ama-assn.org/ama/upload/mm/369/1957principles.pdf.

144. Id. In 1957, the Judicial Council moved the Principles away from addressing specific conduct towards making more abstract statements of ethical standards. Id. The 1957 Principles were based on (1) the 1955 edition of the Principles of Medical Ethics and (2) "[a]bstracts of interpretations of ethical principles made by the Judicial Council since 1900." Id. The 1955 Principles "consisted of a preamble and forty-seven sections" compared to the 1957 Principles' preamble and ten sections. $I d$. The practical effect of broadening the language of the Principles was to " $g[\mathrm{i}] \mathrm{ve}$ the Judicial Council broad rule making authority, allowing them [sic] to issue ethical pronouncements without securing House of Delegates approval." AM. MED. Ass'N, 
ics now consists of the Principles of Medical Ethics and a codified compilation of the Current Opinions of the Council on Ethical and Judicial Affairs ("CEJA"). ${ }^{145}$ Although the CEJA did not issue any formal opinions on physician restrictive covenants at that time, two principles from the 1957 Principles of Medical Ethics are potentially relevant to restrictive covenants. First, the 1957 Principles of Medical Ethics provided that "[a] physician may choose whom he will serve."146 While this principle was likely aimed at a growing concern among physicians that they should not be forced to accept patients, it also arguably addresses the ability of a physician to choose his own patients, even those of a former employer. Second, consistent with the change that occurred in 1922, the 1957 Principles of Medical Ethics provided that a physician "should not solicit patients." 147

In 1980, the Principles of Medical Ethics were again amended to repeal the absolute prohibition on solicitation of patients. ${ }^{148}$ Moreover, two additional principles adopted that year are relevant to physician restrictive covenants. ${ }^{149}$ First, the 1980 Principles of Medical Ethics provided that "[a] physician shall respect the rights of patients... and shall safeguard patient confidences within the constraints of the law."150 Second, the 1980 Principles of Medical Ethics provided that "[a] physician shall recognize a responsibility to participate in activities contributing to an improved community."151

Relying on these two principles, the CEJA eventually opined that restric-

TIMELINES OF AMA HISTORY: 1941- 1960, http://www.ama-assn.org/ama/pub/about-ama/ourhistory/timelines-ama-history/1941-1960.shtml (last visited Mar. 7, 2009). Largely as a result of this change, the AMA Code of Ethics now has two components: (1) the Principles of Medical Ethics which establish broad principles for governing the conduct of physicians, and (2) the current Opinions of the CEJA, which constitute CEJA's application of the Principles to more than 200 specific ethical situations in the medical profession. AM. MED. Ass'N, DEVELOPING AMA POLICIES, http://www.ama-assn.org/ama/pub/about-ama/our-people/house-delegates/ developing-ama-policies.shtml (last visited Mar. 7, 2009). The end of each CEJA opinion includes a Roman numeral reference to the Principle(s) upon which the council relied in formulating its opinion. Id. "The following Principles adopted by the American Medical Association are not laws, but standards of conduct that define the essentials of honorable behavior for the physician.” AM. MED. Ass'N, PRINCIPLES OF MEDICAL ETHCS (1980), available at http://www.ama-assn.org/ama1/pub/upload/mm/369/1980_principles.pdf.

145. AM. MED. Ass'N, DEVELOPING AMA POLICIES, http://www.ama-assn.org/ama/pub/ about-ama/our-people/house-delegates/developing-ama-policies.shtml (last visited Mar. 7, 2009).

146. Am. Med. Ass'N, PRINCIPLes of Medical Ethics (1957), supra note 143, § 5.

147. Id.

148. Am. MEd. Ass'N, Principles of Medical Ethics (1980), supra note 144. The 2001 Principles of Medical Ethics left Sections IV, VI, and VII of the 1980 Principles substantively unchanged. Compare AM. MED. Ass'N, PRINCIPLES OF MEDICAL ETHICS(1957), supra note 143, with AM. MED. Ass'N, PRINCIPLES OF MEDICAL ETHICS (2001), available at http://www.amaassn.org/ama/pub/physician-resources/medical-ethics/ama-code-medical-ethics/principlesmedical-ethics.shtml.

149. The 1980 Principles of Medical Ethics also left unchanged the principle that a physician shall "be free to choose whom to serve...." AM. MED. Ass'N, PRINCIPLES OF MEDICAL ETHICS (1980), supra note 144, § VI.

150. Id. § IV.

151. Id. § VII. 
tive covenants should be discouraged. ${ }^{152}$ The current CEJA opinion was established in 1998, which now discourages the use of any physician restrictive venant:

Covenants-not-to-compete restrict competition, disrupt continuity of care, and potentially deprive the public of medical services. The Council on Ethical and Judicial Affairs discourages any agreement which restricts the right of a physician to practice medicine for a specified period of time or in a specified area upon termination of an employment, partnership, or corporate agreement. Restrictive covenants are unethical if they are excessive in geographic scope or duration in the circumstances presented, or if they fail to make reasonable accommodation of patients' choice of physician. (VI, VII) Issued prior to April 1977; Updated June 1994 and June $1998 .^{153}$

In 2006, CEJA recommended substantive changes to its opinion. ${ }^{154} \mathrm{Re}-$ cognizing that the AMA Code of Medical Ethics "generally promotes patient choice," 155 CEJA recommended language that would encourage physiciansboth employer- and employee-physicians - to be more accommodating of patient choice when entering into restrictive covenants. ${ }^{156}$ When CEJA presented its recommendations to the AMA House of Delegates, however, the proposed amendments were met with "much resistance." 157 The AMA House of Delegates referred the report back to CEJA, which withdrew the report in 2007 after "input from interested constituencies, including representatives from the Advisory Committee on Group Practice Physicians." "158 This recent series of events indicates that the debate over physician restrictive covenants is far from settled and demonstrates a shift towards disfavoring them altogether.

In addition to CEJA's express opinion on restrictive covenants, other CEJA ethical statements affect restrictive covenants. For example, physicians

152. AM. Med. Ass'N, Code of MEdical Ethics (2009), supra note 132, § E-9.02.

153. Id.

154. AM. Med. Ass'N CounCIL on ETHICAL AND Judicial AfF. ReP. No. 5-A-06 at 2:17-20 (withdrawn June 2007 by Rep. No. 8-A-07).

155. Id. at 1:27.

156. See, e.g., id. at 2:43-45 ("Upon entering into a contractual relationship, both parties should establish equitable terms of severance to promote the welfare of patients, in part by facilitating patient choice of physicians.")

157. AM. Med. Ass'N COUNCIL ON ETHICAL AND Judicial AfF. Rep. No. 8-A-07 at 1:10, available at $\mathrm{http}: / / \mathrm{www}$.ama-assn.org/ama1/pub/upload/mm/369/ceja_8a07.pdf.

158. Id. at 1:13-14. Citing the confidentiality of internal deliberations, CEJA has declined to reveal the nature of the concerns raised by the Advisory Committee on Group Practice Physicians. E-mails from Lee Black, Senior Research Associate, AMA Ethics Group, to author (Oct. 22, 2007, 13:47 EST; Oct. 31, 2007, 14:59 EST) (on file with the Indiana Health Law Review). 
are under an ethical duty to put patients' interests above their own self-interest (e.g., avoiding a buyout provision or liquidated damages clause) and above obligations to other groups (e.g., their practice groups). ${ }^{159}$ Also, although physicians are free to turn down a prospective patient, ${ }^{160}$ once the physician-patient relationship is established, physicians may not withdraw from that relationship until they have given sufficient advance notice to allow the patient to secure another physician. ${ }^{161}$

Whether the AMA as an organization will take an even stronger ethical stance against physician restrictive covenants remains to be seen. But recent events reflect an undeniable clash between medical ethicists, who are advocating further limitations on the use of restrictive covenants, and practice groups, who are concerned about the business and financial interests of employers. The larger historical picture, however, reflects a trend towards a stronger position disfavoring physician restrictive covenants as unethical.

\section{(II) Medical ethics in Indiana}

While the views of the national medical community should be considered, even more importantly, Indiana courts should first consider the views of the Indiana medical community on the issue. It was, after all, the Indiana delegation to the AMA House of Delegates that "introduced a resolution that unequivocally declared that restrictive covenants were unethical."162 If the Indiana medical community opposes covenants not to compete as being unethical for physicians, then Indiana law arguably should reflect the industry's sense of public policy. Indiana physicians are governed by the Medical Licensing Board of Indiana. ${ }^{163}$ While the Board's regulations do not expressly prohibit restrictive covenants, they do require respect for patients' rights ${ }^{164}$ and for avoiding disruption in patient care. ${ }^{165}$

\section{b. The patient's right to choose a physician}

Perhaps the most overlooked public concern so far in Indiana courts has been the interests of patients that are affected by restrictive covenants, especial-

159. AM. MED. Ass'N, Code of MEdiCAL Ethics (2009), supra note 132, § E-10.015.

160. Id. § $\mathrm{E}-9.06$.

161. Id. § $\mathrm{E}-8.115$.

162. Berg, supra note 32 , at 7.

163. IND. CODE $\S 25-22.5-2-7$ (2008).

164. 844 IND. ADMIN. CODE 5-2-4 (2007) (providing that physicians may not withdraw from providing care until they have given sufficient advance notice in advance to allow the patient to secure another physician).

165. 844 IND. ADMIN. CODE 5-2-16(b) (2007) (providing that a physician who retires from practice, discontinues a practice, or moves away from the community must notify all of his or her active patients in writing that the practice is being discontinued and that the patient should seek another physician). Although beyond the scope of this Note, it is interesting to consider the possible conflict between this ethical regulation and a non-solicitation agreement. 
ly insofar as a restrictive covenant impinges on the patient's ability to select the physician of his choosing or to ensure continuity of care for long-term diseases. Here again, the AMA's Code of Medical Ethics is instructive and recognizes the right of patients to freely choose their physicians: "Free choice of physicians is the right of every individual."

Courts should be even more vigilant to protect patient interests because these patients, many of whom may be more intimately affected in matters of life and death by the non-compete agreements than either the physician-employee or the employer, are not represented in the bargaining of the physician employment agreement. Moreover, most patients are not aware of the existence of such agreements and have no way of "shopping" for physicians that are not bound to restrictive covenants.

As a matter of priority, it has been shown that patients would rather have the right to choose their individual physicians than to choose a particular health insurance plan. ${ }^{167}$ There is also a correlation between patients' choice of doctors and patients' satisfaction in their medical care. According to one study, patients "who had a limited choice of where to go for care were more dissatisfied than those with few plan choices."168 This freedom of choice is so important to patients that they are willing to pay more out of their own pockets for health insurance if doing so means they can have an unrestricted choice of physicians. ${ }^{169}$ Patients have greater confidence in the physicians that they themselves have chosen. ${ }^{170}$

Finally, the ability of patients to freely choose their physician increases the quality of health care on the whole. First, one byproduct of increased patient confidence is a greater likelihood that patients will seek timely and appropriate care from their physician of choice. ${ }^{171}$ Second, the freedom of choice facilitates patients' ability to preserve continuity of care in cases where it is important to them, such as prenatal care or chronic illnesses. ${ }^{172}$ Patients themselves indicate that the most important reason for having a choice in physicians is the ability to control the quality of their care. ${ }^{173}$

While restrictive covenants hinder a patient's ability to select a physician, the use of liquidated damages clauses and narrow geographical limitations may adequately accommodate a patient's right to choose his physician. ${ }^{174}$ If the

166. AM. Med. Ass'N, Code of Medical Ethics (2009), supra note 132, § E-9.06.

167. Jeanne M. Lambrew, "Choice" in Health Care: What Do People Really Want?, IssuE BrIEF, (The Commonwealth' Fund, New York, N.Y.), Sept. 2005, at 3, available at http://www.commonwealthfund.org/usr_doc/lambrew_853_choice_ib.pdf?section=4039.

168. Id.

169. U.S. Advisory Comm'n on Consumer Prot. and QualtTy In the Health Care INDUS., QUALITY FIRST: BETTER HEALTH CARE FOR ALL AMERICANS app. A, ch. 2 (1998), availa-

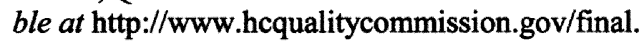

170. Id.

171. Id.

172. Id.

173. Id.

174. St. Clair Med., P.C. v. Borgiel, 715 N.W.2d 914, 921 (Mich. Ct. App. 2006) (per 
physician pays liquidated damages, he or she is allowed to practice in the restricted area, and any current patient's rights are adequately protected. Similarly, if the geographic limitation is sufficiently narrow, for example a restriction covering a seven-mile-radius, ${ }^{175}$ the departing physician's current patients would be able to continue their treatment without undue travel burdens. The less distance the patient is required to travel to maintain continuity of treatment, the less of a burden the restrictive covenant places on the patient's right to choose. Thus, courts should consider the scope of a restrictive covenant's geographic limitation in light of the burden it places on a patient's right to seek continuing care, as well as other conditions that may affect the patient's right to choose.

\section{c. Physician shortages in Indiana}

Another relevant public interest consideration is whether the particular restricted geographic area suffers from a physician shortage. If the restricted area already has a physician shortage, enforcing the non-compete agreement will only exacerbate the problem. This problem is particularly acute in Indiana, where nearly half of Indiana's counties ${ }^{176}$ contain areas that have been designated by U.S. Health and Human Services as a "Health Professional Shortage Area" in "Primary Medical Care." 177 Moreover, more than sixty percent of Indiana counties ${ }^{178}$ contain areas that have been designated by U.S. Health and Human Services as a "Medically Underserved Area." 179 Taking those statistics together, more than two thirds of Indiana's ninety-two counties contain areas that have been designated by U.S. Health and Human Services as either a

curiam) ("Moreover, patients' choice of physician is protected by the modest geographical scope of the covenant [seven-mile radius] and the liquidated damages clause").

175. Id. (holding that a seven-mile-radius restriction would not interfere with the patient's right to choose a physician).

176. HEAlTH PROFESSIONAL SHORTAGE AREAS, supra note 33. Forty-five of Indiana's ninety-two counties contain areas that have been designated as "Health Professional Shortage" areas: Allen, Clark, Clay, Crawford, Daviess, Delaware, Elkhart, Fountain, Grant, Greene, Hendricks, Henry, Howard, Jasper, Jennings, Johnson, La Porte, Lagrange, Lake, Madison, Marion, Martin, Miami, Newton, Owen, Parke, Perry, Porter, Pulaski, Putnam, Randolph, Rush, Scott, Spencer, St. Joseph, Starke, Sullivan, Switzerland, Tippecanoe, Vanderburgh, Vermillion, Vigo, Warren, Wayne, and White Counties. Id.

177. For the criteria used by the U.S. Department of Health and Human Services to designate an area having a shortage of primary medical care professionals, see 42 C.F.R. pt. 5, app. A (2008).

178. MEDICALLY UNDERSERVED AREAS, supra note 33. Fifty-six of Indiana's ninety-two counties contain areas designated as "Medically Underserved": Allen, Brown, Carroll, Cass, Clark, Clay, Clinton, Crawford, Daviess, Decatur, Delaware, Elkhart, Fayette, Floyd, Franklin, Gibson, Grant, Greene, Howard, Huntington, Jackson, Jefferson, Jennings, Johnson, Knox, Lake, LaPorte, Madison, Marion, Martin, Miami, Monroe, Newton, Ohio, Orange, Owen, Parke, Perry, Pike, Porter, Posey, Ripley, St. Joseph, Scott, Spencer, Starke, Sullivan, Switzerland, Tippecanoe, Union, Vanderburgh, Vermillion, Vigo, Warren, Washington, and White Counties.

179. For the criteria used by the U.S. Department of Health and Human Services to designate an area as a medically underserved area, see U.S. DEP'T OF HEALTH AND HUMAN SERV., HEAlth Res. AND SERV. AdMIN., GUIDELINES fOR MEDICALly UNDERSERVED AREA AND POPULATION DESIGNATION (2007), http://bhpr.hrsa.gov/shortage/muaguide.htm. 
"Medically Underserved Area" or a "Health Professional Shortage Area" in "Primary Medical Care." 180 The physician shortage is a particularly widespread problem in Indiana. ${ }^{181}$

At least one Indiana court has explicitly invoked the public's interest in avoiding physician shortages. In Fumo v. Medical Group of Michigan City, Inc. ${ }^{182}$ the trial court granted the plaintiff medical group's request for a preliminary injunction to enforce Dr. Fumo's covenant not to compete after Dr. Fumo voluntarily resigned. On appeal, the Indiana Court of Appeals dissolved the preliminary injunction because the trial court failed to make any finding that the public interest would not be harmed. ${ }^{183}$ Concerned about a shortage of medical services in the restricted area, the Indiana Court of Appeals specifically instructed the trial court on remand to consider "the availability of the particular specialty practiced by the physician...."184 The court stated that "[w]here a specialist offers services uniquely or sparsely available in a specified geographical area, an injunction may be unwarranted because the movant is unable to meet the burden of showing that the public would not be disserved."185 Therefore, a thorough and serious evaluation of the public interest requires that Indiana courts determine whether enforcing a physician restrictive covenant will either aggravate or alleviate the shortage of physicians in the state.

\section{d. Comparison to attorney non-compete agreements}

In the context of attorney employment agreements, restrictive covenants unquestionably violate public policy and legal ethics in Indiana. ${ }^{186}$ Many of the same justifications for refusing to enforce attorney restrictive covenants apply with equal, if not greater, force to physician restrictive covenants. There are at least four justifications for the rule prohibiting lawyers from entering into noncompete agreements. First, the official comment to the Indiana Rules of Pro-

180. HeAlth Professional ShORTAGE AREAS, supra note 33; MEDiCALly UNDERSERVED AREAS, supra note 33. Sixty-seven of Indiana's ninety-two counties contain areas designated as either "Medically Underserved" or having a "Health Professional Shortage": Allen, Brown, Carroll, Cass, Clark, Clay, Clinton, Crawford, Daviess, Decatur, Delaware, Elkhart, Fayette, Floyd, Fountain, Franklin, Gibson, Grant, Greene, Hendricks, Henry, Howard, Huntington, Jackson, Jasper, Jefferson, Jennings, Johnson, Knox, La Porte, Lagrange, Lake, LaPorte, Madison, Marion, Martin, Miami, Monroe, Newton, Ohio, Orange, Owen, Parke, Perry, Pike, Porter, Posey, Pulaski, Putnam, Randolph, Ripley, Rush, Scott, Spencer, St. Joseph, Starke, Sullivan, Switzerland, Tippecanoe, Union, Vanderburgh, Vermillion, Vigo, Warren, Washington, Wayne, and White Counties.

181. But see Med. Specialists, Inc. v. Sleweon, 652 N.E.2d 517, 525-27 (Ind. Ct. App. 1995) (rejecting statistics of the U.S. Department of Health and Human Services as overly broad in favor of testimony that no patient had ever been refused treatment for a particular specialty).

182. 590 N.E.2d 1103 (Ind. Ct. App. 1992).

183. Id. at $1108-09$.

184. Id. at 1109.

185. Id. (emphasis added).

186. IND. RULES OF PROF. CONDUCT 5.6(a) (2008) (prohibiting lawyers generally from making or offering agreements restricting the right of the lawyer to practice law). 
fessional Conduct expressly states that a restrictive covenant is unethical for a lawyer because it "limits [the lawyers'] professional autonomy...."187 Although the comment and rules may not explicitly say so, the purported principle behind this concern for the lawyer's professional autonomy is the lawyer's related duty to exercise independent professional judgment. ${ }^{188}$ But a physician is under no less a duty than lawyers to exercise independent professional judgment when providing medical services. ${ }^{189}$ Even so, it is unclear why the professional autonomy of a lawyer is more worthy of protection than the professional autonomy of physicians.

Second, the official comment to the Indiana Rules of Professional Conduct also justifies its rule based on the "freedom of clients to choose a lawyer." 190 Again, why is the freedom of clients to choose a lawyer more important than the freedom of patients to choose a doctor? Arguably, consumers have a stronger interest in freely choosing their physician than in freely choosing their lawyer, because medical services affect a patient's highly personal interest in bodily integrity, whereas legal services generally affect only a client's economic and financial interests (although admittedly that is not always the case). The fact that patients are willing to pay more for the freedom to choose their physician $^{191}$ supports the proposition that consumers value interests in their own health and bodily integrity over their own financial and economic interests.

Third, other authorities have relied on the important public service that attorneys provide and the duty to make those services available to the public to justify the ban on attorney non-compete agreements. ${ }^{192}$ The services of physicians, however, are no less important (and arguably more important) to the public than the services of attorneys. Moreover, physicians are likewise under an ethical duty to make their services widely available to the public. ${ }^{193}$

Finally, ethical prohibitions on attorney restrictive covenants have been justified based on the attorney's confidential and fiduciary relationship with the client. ${ }^{194}$ As with attorneys, physicians are likewise engaged in a confidential

187. Id. at 5.6, cmt. 1 .

188. Id. at 5.4(c) (prohibiting a lawyer from allowing a third party, including an employer, to direct the lawyer's professional judgment in rendering legal services).

189. E.g., AM. MED. Ass'N, CODE OF MEDICAL ETHICs (2009), supra note 131, § E-8.041 (requiring physicians who provide second opinions to exercise independent professional judgment).

190. IND. RULES OF PROF. CONDUCT 5.6(a), cmt. 1 (2008).

191. See supra pp. 38-41.

192. See, e.g., Dwyer v. Jung, 336 A.2d 498, 501 (N.J. Super. Ct. Ch. Div. 1975)(refusing to enforce an attorney restrictive covenant based in part on the duty of attorneys to make services fully available to the public); Murfreesboro Med. Clinic, P.A. v. Udom, 166 S.W.3d 674, 683 (Tenn. 2005) (recognizing the duty shared by both physicians and attorneys alike to make their respective services available to the public).

193. See AM. Med. Ass'N, Code OF Medical Ethics (2009), supra note 132, § E-9.065 (ethical obligation to care for the indigent); $i d$. § E-9.067 (ethical obligation to provide services in event of public disaster).

194. Karlin v. Weinberg, 390 A.2d 1161, 1171 (N.J. 1978) (Sullivan, J., dissenting) 
and fiduciary relationship with their patients. ${ }^{195}$ Not only do ethics rules expressly recognize the fiduciary nature of both the physician-patient and the attorney-client relationships, but deep-rooted evidentiary rules also recognize the importance of protecting confidential communications in both relationships. ${ }^{196}$

The public service of both physicians and attorneys, as well as the nature of the relationship between the two professions and their respective clients or patients, are very similar, yet the rules governing restrictive covenants in the two professions exhibit a glaring disparity. This lack of any substantive difference between physicians and attorneys leaves one wondering whether the disparity in the rules simply reflects an arrogant self-assessment of the legal profession's value to the public. Rather, the public importance of physician services ought to be similarly recognized by subjecting physician non-compete agreements to more rigorous review.

\section{The Circumstances Surrounding the Physician's Departure}

This Note thus far has advocated a more faithful application of the traditional analysis, namely, that courts should more strictly scrutinize both the employer's alleged protectable interests as well as the restrictive covenant's impact on the public interest. There are, however, other considerations that may not necessarily fit neatly within the traditional framework but are nonetheless appropriate and relevant to a "more exacting" review of the restrictive covenant's overall reasonableness and fairness. One such consideration is the circumstances surrounding the physician's termination, particularly where the court is called upon to exercise its equitable powers. ${ }^{197}$ Logically, the circumstances of the employee-physician's termination will generally fall into one of three possible categories: (1) the physician voluntarily resigns or the employer terminates the physician for cause, (2) the employer in good faith terminates the physician but without cause, or (3) the employer terminates the physician in bad faith. While the circumstances surrounding the physician's departure should be considered as a factor, they need not be the determinative factor. ${ }^{198}$ Each situation identified above raises a different set of equities that warrant differing factorial weights, as discussed below.

195. AM. MED. Ass'N, CODE OF MEDICAL ETHICs (2009), supra note 132, § E-10.01 (physician must not reveal confidential communications with a patient); id. $\$ \mathrm{E}-10.015$ (physicianpatient relationship is based on trust and physician's fiduciary responsibilities to patient).

196. IND. CODE § 34-46-3-1(1) (2007) (privilege for attorney-client communications); id. § 34-46-3-1(2) (privilege for physician-patient communications).

197. See, e.g., Gomez v. Chua Med. Corp., 510 N.E.2d 191, 195 (Ind. Ct. App. 1987) ("If the termination is made in bad faith, equity may be called upon to deny enforcement [of the restrictive covenant]....").

198. See Kenneth J. Vanko, “You're Fired! And Don't Forget Your Non-Compete... ": The Enforceability of Restrictive Covenants in Involuntary Discharge Cases, 1 DEPAUL BUS. \& COM. L.J. 1, 16-17 (2002) (criticizing reliance on the circumstances of an employee's termination as sole consideration in determining whether to enforce a non-compete agreement). 


\section{Voluntary Resignation or Termination for Cause}

This first situation presents the easiest case for enforcement for a couple of reasons. First, it is arguably the exact situation that the employer sought to protect against when requiring the restrictive covenant in the first place, i.e., the physician-employee voluntarily leaves before the employer has recovered its capital investment. Additionally, the employee could have avoided the covenant's adverse effects simply by continuing employment or refraining from his bad conduct. In other words, the employee in this situation is in control of the restrictive covenant's application. As for the rights of the patients to obtain continuing care, as long as the physician gives them sufficient notice to find a replacement physician, this situation is no different than if the physician simply withdrew from practice. ${ }^{199}$ Thus, a physician's voluntarily resignation should weigh in favor of enforcing the restrictive covenant.

Two Indiana cases illustrate this observation, although neither decision expressly acknowledges that the circumstances surrounding the physicians' termination should be a separate consideration. The first case is Raymundo $v$. Hammond Clinic Association ${ }^{200}$ which was previously discussed above at length in Section III.B. The facts and outcome of Raymundo are consistent with the theory that the employee's voluntary resignation weighs in favor of enforcement. In Raymundo, Dr. Raymundo signed a five-year partnership agreement but voluntarily withdrew from the partnership after only two years to begin his own independent practice. ${ }^{201}$ The Raymundo court upheld the restrictive covenant because "[it] did nothing more than protect the Clinic's goodwill against piracy by a mutinous partner."202 Thus, without expressly acknowledging the effect that Dr. Raymundo's voluntary resignation had on the enforceability of the restrictive covenant, the Raymundo court may have been persuaded by Dr. Raymundo's voluntary withdrawal from the partnership. ${ }^{203}$

Second, Central Indiana Podiatry, P.C. v. Krueger ${ }^{204}$ illustrates how an employee's termination for cause may help justify enforcing the restrictive covenant. In Krueger, a female employee complained that Dr. Krueger had tried to kiss her while they were working together in the clinic's Kokomo, Indiana office. ${ }^{205}$ In the clinic's ensuing investigation, Dr. Krueger admitted not only to that incident but also to an incident with another employee involving "some

199. 844 IND. ADMIN. CODE 5-2-16(b) (2007) (providing that a physician who retires from practice, discontinues a practice, or moves away from the community, must notify all of his or her active patients in writing that the practice is being discontinued and that the patient should seek another physician).

200. 449 N.E.2d 276 (Ind. 1983).

201. Id. at $277-78$.

202. Id. at 279.

203. Id. at 278.

204. 882 N.E.2d 723 (Ind. 2008).

205. Id. at 726 . 
sort of touching."206 Anticipating that the clinic would terminate him, Dr. Krueger took a list of his current patients. ${ }^{207}$ The clinic then terminated Dr. Krueger. ${ }^{208}$ Again, as with Raymundo, the Krueger court nowhere expressly discusses whether Dr. Krueger's conduct has any effect on the restrictive covenant's enforceability, but the court did enforce the covenant, at least in part. ${ }^{209}$

There may be a downside, however, to relying on a "for cause" termination as a factor in determining whether to enforce a covenant not to compete. If employers understand that terminating a physician "for cause" will weigh in favor of enforcement, they may try to create a pretextual reason for termination to enhance the likelihood that the covenant not to compete will be enforced. Moreover, any subsequent litigation as to the enforceability of the restrictive covenant may become unduly focused on the collateral issue of whether the employer had "just cause" for the termination. ${ }^{210}$ If this factor was determinative, such concerns would probably be justified. But a "for cause" termination should merely be one of many factors, making it unlikely that employers will try to find excuses to terminate a physician or that the existence of cause will dominate the litigation.

\section{Bad Faith Termination}

If a physician's voluntary resignation makes an easier case for enforcement, an employer's bad faith similarly makes an easier case for refusing to enforce the restrictive covenant. Although there are no Indiana cases directly on point, ${ }^{211}$ a Seventh Circuit case from neighboring Illinois is illustrative. In Rao v. $R a o,{ }^{212}$ the employee surgeon entered into an employment agreement with a surgery practice group that would have allowed him to purchase a fiftypercent ownership in the practice for one dollar after four years of service. ${ }^{213}$ The agreement also provided that if the employee surgeon was terminated "for any reason" before acquiring his ownership interest, he would be subject to a restrictive covenant. ${ }^{214}$ Although the employer and employee enjoyed a good working relationship, the employer sent a notice of intent to terminate the employee, effective a mere ten days before the employee became eligible to pur-

206. This fact is omitted from the Indiana Supreme Court's opinion but was included in the lower appellate court's decision. See Krueger, 859 N.E.2d at 689.

207. Krueger, 882 N.E.2d at 726.

208. Id.

209. Id. at 734.

210. For a discussion of the problems with the "for cause/without cause" distinction in evaluating restrictive covenants, see Vanko, supra note 198, at 23-25.

211. There is dictum, however, indicating that Indiana courts would be willing to refuse to enforce a restrictive covenant in the face of an employer's bad faith. Gomez v. Chua Med. Corp., 510 N.E.2d 191, 195 (Ind. Ct. App. 1987) ("If the termination is made in bad faith, equity may be called upon to deny enforcement [of the restrictive covenant]....").

212. 718 F.2d 219 (7th Cir. 1983).

213. Id. at 221.

214. Id. 
chase the fifty-percent ownership interest. ${ }^{215}$ Moreover, the letter containing the notice of intent to terminate invited the employee to negotiate a "new relationship" with the employer. ${ }^{216}$ Thus, the only apparent reason that the employer terminated the employee was to prevent the employee from exercising his buy-in option under the agreement. ${ }^{217}$ When the employee continued to practice surgery in violation of the restrictive covenant, the employer brought suit to enforce the covenant. ${ }^{218}$ Applying Illinois law, the Seventh Circuit held that because the employer terminated the employee in bad faith and without cause, it was precluded from enforcing the restrictive covenant. ${ }^{219}$

The existence of an employer's bad faith should weigh heavily in favor of refusing to enforce a restrictive covenant primarily because, as the Rao court recognized, the necessity for a restrictive covenant in such a case is virtually nonexistent. ${ }^{220}$ Obviously, an employer requires an employee to sign a noncompete agreement out of a concern that the employee will quit and begin competing with the employer. If the employer is so concerned about competition, then it should not terminate the employee-especially in bad faith. In such a case, the employer certainly does not suffer injustice if the restrictive covenant is not enforced. Thus, a bad faith termination by the employer should weigh heavily in favor of refusing to enforce a non-compete agreement. ${ }^{221}$

\section{Good Faith Termination Without Cause}

Perhaps the most difficult situation is where an employer terminates an employee without cause but does so in good faith. In this situation, the employer may have a number of legitimate reasons for terminating the employee other than the employee's misconduct, such as purely business or financial reasons. The Indiana Court of Appeals had occasion to address this situation in Gomez v. Chua Medical Corp. ${ }^{222}$ There, Dr. Gomez was terminated without cause and set up his own practice in violation of a restrictive covenant in his employment agreement. ${ }^{223}$ The court of appeals expressly rejected Dr. Gomez' argument that the employer should have to prove it had "good cause" to terminate him as a condition to enforcing the restrictive covenant. ${ }^{224}$ In rejecting this argument, the court expressed concern that such a rule would invite excessive

215. Id.

216. Id.

217. Id. at 222.

218. Id. at 221 .

219. Id. at 224.

220. Id.

221. One commentator has criticized an approach that focuses solely on the existence of bad faith as the determinative factor. Vanko, supra note 197, at 25-26. The approach advocated here, however, considers the existence of bad faith merely as one factor, albeit a relatively heavily weighted factor.

222. 510 N.E.2d 191 (Ind. Ct. App. 1987).

223. Id. at 193.

224. Id. at 195 . 
litigation over whether "good cause" existed. ${ }^{225}$ The court was also persuaded by the strong public interest in the freedom to contract, including the freedom to enter into contracts that are "unwise or even foolish.",226

On the one hand, the freedom to contract acknowledges that the employee-physician should have appreciated the risk of a "termination without cause" in negotiating his employment agreement. Because the clinic did not act in bad faith, it should not be penalized for a condition that is reflected in the bargain. Moreover, if an employer terminated the employee for financial reasons, then the employer is presumably struggling financially, arguably heightening its need to enforce the restrictive covenant in order to survive.

On the other hand, enforcing a restrictive covenant in this situation is unfair to the employee-physician because he is willing and able to work for the employer rather than to compete against it. The employer has a legitimate interest in requiring a restrictive covenant to protect its investment in its employees - whether a financial, educational, or informational investment- to ensure that the investment produces a return for the benefit of the employer rather than its competitors. But if the employer voluntarily relinquishes the ability to profit from that investment by prematurely terminating the employee, it is unfair to burden the employee (who is otherwise willing to produce a return for the employer) with finding a different market in which to benefit from that investment. Thus, to a certain extent, enforcing a restrictive covenant in this situation gives the employer more protection than the scope of his legitimate interests.

The parties on both sides of this situation have strong equitable arguments. When weighing the circumstances surrounding the physician's termination without cause and in good faith, the balanced interests suggest giving this factor neutral weight in the final analysis. Treating this factor neutrally may mitigate concerns that the litigation will be unnecessarily consumed with whether the employer had "good cause" to terminate the employee. While the employer need not prove good cause, it may present evidence of good cause to bolster its case for enforcing the restrictive covenant.

\section{Consideration of the Remedy Sought}

Another potential factor in evaluating whether to enforce a physician's restrictive covenant is the type of remedy that the employer is seeking. Employment agreements with restrictive covenants sometimes include a waiver provision whereby the employee may pay a pre-determined amount as liqui-

225. Id.

226. Id. Perhaps more accurately, the court felt constrained by the Indiana Supreme Court's decision in Raymundo. 449 N.E.2d 276 (Ind. 1983). In a concurring opinion, a majority of the panel indicated that, but for the Indiana Supreme Court's decision in Raymundo, it would have been willing to strike down the restrictive covenant as against public policy. Gomez, 510 N.E.2d at 196-97 (Sullivan, J., concurring). 
dated damages for the privilege of violating the restrictive covenant. ${ }^{227}$ Thus, employers may seek to enforce the employment agreement either by obtaining injunction relief against the physician's competing practice or by obtaining a liquidated damages award. The type of remedy sought affects the analysis of the public's interest and should be considered independently.

\section{Liquidated Damages}

Liquidated damages are less burdensome on public interests than an injunction restraining the physician from practicing medicine. While the physician may personally suffer by incurring the additional costs of liquidated damages, the public nonetheless benefits through the physician's continued services. Of course, it could be argued that if the liquidated damages are too steep, the physician will be forced to submit to the restrictive covenant and withdraw from practice. While that argument certainly presents a legitimate concern, there are two mitigating considerations here. First, liquidated damages must not be grossly disproportionate to the potential losses that the nonbreaching party will suffer. ${ }^{228}$ This rule protects against overreaching and exorbitant liquidated damages amounts. Second, even in the absence of a restrictive covenant, a physician is free to leave his practice at any time. Nothing in the law requires him to practice. Thus, even if the physician chooses to submit to the restrictive covenant rather than pay the liquidated damages, at least a liquidated damages provision gives him the option to make that decision rather than having it forced on him.

\section{Injunctive Relief}

Unlike a liquidated damages remedy, if injunctive relief is sought, a doctor who wants to continue practicing will be prevented from providing medical services. This forced withdrawal of medical services will more substantially burden both the public's interest in having a physician's services available and an individual patient's interest in freely choosing the highly personal services that a physician provides. In the seminal Indiana case on this subject, Raymundo v. Hammond Clinic Association, ${ }^{229}$ the Indiana Supreme Court did not have occasion to consider the injunctive remedy for enforcing a restrictive covenant, a fact that has been overlooked in subsequent Indiana decisions. In fact, the court stated, "[W]e are here concerned only with the paragraph [of the com-

227. See, e.g., Raymundo, 449 N.E. 2 d at 276 (liquidated damages of $\$ 25,000$ for a violation during the first year of the two-year restrictive covenant and $\$ 15,000$ for a violation during the second year); Gomez, 510 N.E.2d at 191 (liquidated damages of $\$ 50,000$ to practice in violation of the restrictive covenant); Sharvelle v. Magnante, 836 N.E.2d 432 (Ind. Ct. App. 2005) (agreement provided that the employer will waive the restrictive covenant in exchange for payment of $\$ 300,000$ as liquidated damages).

228. Gomez, 510 N.E.2d at 193.

229. Raymundo, 449 N.E.2d 276. 
plaint] seeking damages, [since the request for injunctive relief] ha[s] become moot with the passage of time, during the pendency of the action in the trial court...."230 Therefore, a close and narrow reading of Raymundo reveals that the Indiana Supreme Court has not yet considered the precise issue of whether a physician restrictive covenant may be enforced by injunctive relief.

Due to the heightened burden on the public interest and on patients' rights that an injunction may impose, courts should weigh a request for injunctive relief in favor of refusing to enforce a restrictive covenant. As with the other factors, this factor need not be determinative, but should be taken into consideration in light of the other factors to consider.

\section{E. Heightened Burden of Proof for Enforcement: Clear and Convincing Evidence}

Finally, a more scrutinizing review of non-compete agreements could include imposing a greater burden of proof for the employer. Although the question of a restrictive covenant's reasonableness is a question of law, ${ }^{231}$ this determination must nonetheless be based on facts relevant to the traditional inquiry, such as facts surrounding the employer's protectable interest and any adverse effects on the public. While a heightened burden of proof on the employer has not yet been discussed in any Indiana case, a line of cases from neighboring Ohio has imposed the clear and convincing standard on employers seeking to enforce restrictive covenants. In Ohio Urology, Inc. v. Poll, ${ }^{232}$ the employer sought to enforce a restrictive covenant contained in the physicianemployee's employment agreement upon the employee's departure. The trial court granted the employee's motion for summary judgment on the grounds that the covenant violated public policy and was per se unenforceable. ${ }^{233}$ The Court of Appeals of Ohio reversed, rejecting the "per se invalid" rule in favor of the "demanding scrutiny" rule. ${ }^{234}$ Although the court remanded the case for a full hearing on the issue of the employer's entitlement to a preliminary injunction, it noted that the disfavored status of restrictive covenants placed a burden on the employer "of producing clear and convincing evidence as to each element [of the traditional rule]." 235

In the usual civil case, the plaintiff must prove its case by a preponderance of the evidence. ${ }^{236}$ But in the usual civil case between two private parties there

230. Id. at $278-79$.

231. Id. at 280 .

232. See, e.g., Ohio Urology, Inc. v. Poll, 594 N.E.2d 1027, 1032 (Ohio Ct. App. 1991) (employer must prove each element of the reasonableness test by clear and convincing evidence).

233. Id. at 1030.

234. Id. at $1031-32$.

235. Id. at 1032.

236. See, e.g., Bonnell v. Sabbagh, 670 N.E.2d 69, 71 (Ind. Ct. App. 1996) ("The general rule in Indiana is that, in civil actions, the rights of the parties are to be determined by a prepon- 
is generally little concern that enforcing one party's rights will have an adverse impact on the public interest. Given the possible adverse effects that enforcing a physician's restrictive covenant may have on the public interest, requiring the employer to prove each element of its case by clear and convincing evidence provides a greater level of certainty that the public will not suffer as a result of enforcing the employer's private rights.

A heightened burden of proof may not make much difference with respect to some of the facts necessary to determine reasonableness, such as the geographic scope of the restriction, the time limits of the restriction, or the scope of prohibited activities. But it would require the employer to prove with clear and convincing evidence that he has legitimate business interests that must be protected by a restrictive covenant. A heightened evidentiary requirement may discourage the use of restrictive covenants except where there is a greater need to protect tangible (i.e., provable) business interests.

\section{CONCLUSION}

The standard for reviewing physician restrictive covenants under current Indiana law is not entirely clear. The Krueger court indicated it was following the earlier Raymundo decision, in which a physician's covenant not to compete was simply held to a reasonableness standard - the same standard that applies to a shoe salesman's covenant not to compete. ${ }^{237}$ On the other hand, Krueger court also indicated that physician non-compete agreements "should be given particularly careful scrutiny.",238

In the commercial context, the abbreviated analysis prevalent in Raymun$d o$ adequately weighs the public's economic interests in securing a competitive marketplace against the employer's business interests. ${ }^{239}$ But in the context of a physician's services, the public's interests are not solely economic. Instead, those interests extend to a patient's interest in uninterrupted treatment of longterm illnesses, a patient's interest in choosing which doctor will perform highly personal services that affect his bodily integrity, and the public's interest in preventing physician shortages that impact overall public health-interests which Indiana's current approach fails to adequately consider.

A rule that physician restrictive covenants are per se invalid certainly recognizes the public's broader interests and provides bright-line guidance to both employers and employees, but it ignores the legitimate need of employers to protect their investment in hiring and training physician employees. It also denies the flexibility needed to recognize that in some instances the public's interest may actually be furthered by enforcing a physician restrictive covenant.

Rather, Indiana courts should subject physician restrictive covenants to a more stringent standard than other commercial covenants not to compete. A

derance of the evidence.").

237. Cent. Ind. Podiatry, P.C. v. Krueger, 882 N.E.2d at 723, 728 (Ind. 2008).

238. Id. at 729.

239. See supra pp. 5-6. 
more exacting scrutiny of physician restrictive covenants, as at least suggested by the Krueger court, will require a strict and faithful application of the traditional rules. ${ }^{240}$ This approach would require an employer to prove its legitimate protectable business interests and the absence of harm to the public before its restrictive covenant could be enforced. Indiana courts should deliberately consider all aspects of the public's interest, including whether enforcement may actually enhance access to medical services. In determining whether the restriction is "reasonable," courts should also consider (1) whether the employee voluntarily left the employment or was terminated for cause, (2) whether the employer terminated the employee without cause, and if so whether such termination was in good faith, (3) whether the agreement adequately provides for the rights of existing patients to follow a physician to a new practice, and (4) whether the agreement's remedy includes payment of damages or is limited to injunctive relief.

Ultimately, the Legislature is responsible for declaring the public policy of the state and should adopt a statutory response with these principles in mind. But even in the absence of legislative action, Indiana courts should not hesitate to aggressively protect the public's interest in the availability of medical services. Such action by the courts, at least in the context of physician restrictive covenants, should not be perceived as an affront on the Legislature's prerogative in setting the public policy of the state, but rather a faithful application of a long-standing rule requiring the judiciary to evaluate the public effects of enforcing a private right. By doing so, Indiana courts can do their part to ensure that Hoosier patients will have the access they need to adequate medical services, while enabling employers to protect their investment in training and hiring the next generation of physicians. 
